\title{
A critical review of laparoscopic total hysterectomy versus laparoscopic supracervical hysterectomy
}

\author{
Anwar Moria • Togas Tulandi
}

Received: 23 August 2010 /Accepted: 8 September 2010 /Published online: 5 October 2010

(C) Springer-Verlag 2010

\begin{abstract}
The purpose of our review is to evaluate the perioperative characteristics of laparoscopic total hysterectomy (LTH) and laparoscopic supracervical hysterectomy (LASH) including the hospital stay, hemoglobin concentration, the operative time, postoperative analgesia, intra and postoperative complications. We also examine the quality of life examining general health, sexual satisfaction, dyspareunia and time to first intercourse
\end{abstract}

Keywords Laparoscopic total hysterectomy · Laparoscopic supracervical hysterectomy

\section{Introduction}

Hysterectomy is the most common gynecological procedure. It is estimated that the rate of hysterectomy is 346 per 100,000 women in Canada and 550 per 100,000 women in the United States $[1,2]$.These rates are over twofolds of that in Britain, Sweden, the Netherlands and Norway [3]. There are different types of hysterectomy. The most common is abdominal hysterectomy comprising $66 \%$ of all hysterectomies followed by the vaginal hysterectomy [4]. Since early nineties, laparoscopic hysterectomy has gained popularity due to its known advantages including short hospital stay, minimal wound related complications and rapid recovery.

Laparoscopic hysterectomy could be divided into laparoscopic assisted vaginal hysterectomy (LAVH), laparoscopic total hysterectomy (LTH) and laparoscopic

\footnotetext{
A. Moria $(\bowtie) \cdot T$. Tulandi

Department of Obstetrics and Gynecology, McGill University, Montreal, QC, Canada

e-mail: anwar.moria@mail.mcgill.ca
}

supracervical hysterectomy (LASH). The proponents of LASH believe that preserving the cervix plays an important role in sexual function, it maintains the pelvic floor support and prevents denervation of bladder and bowel [5-7]. Others feel that there is no strong evidence to support those claims [8-10].

The purpose of our review is to evaluate the perioperative characteristics of LTH and LASH including the hospital stay, hemoglobin concentration, the operative time, postoperative analgesia, intra and postoperative complications. We also examine the quality of life examining general health, sexual satisfaction, dyspareunia and time to first intercourse.

\section{Source of data}

We performed a literature search using the keywords "hysterectomy, laparoscopic hysterectomy, total hysterectomy, supracervical hysterectomy and subtotal hysterectomy" and conducted the search in the Medline, OVID, EMBASE and the Cochrane of Database of systematic reviews published between 1990 and 2010. We found two prospective trials, four retrospective analyses, and two quality-oflife analysis (Table 1). The only randomized study was published in Italian language and we could only evaluate its abstract. Table 2 shows the demography of patients who underwent LTH or LASH.

\section{Operating time, hospital stay and blood loss}

Table 3 shows the operating time, hospital stay and hemoglobin $(\mathrm{Hgb})$ concentration in women who underwent LASH or LTH. 
Table 1 Studies comparing laparoscopic total hysterectomy (LTH) and laparoscopic supracervical hysterectomy (LASH)

\begin{tabular}{|c|c|c|c|}
\hline Authors & Design & $\begin{array}{l}\text { Number of } \\
\text { patients }\end{array}$ & Author's conclusion \\
\hline $\begin{array}{l}\text { Morelli et al. } \\
2007[25]\end{array}$ & $\begin{array}{l}\text { Randomized } \\
\text { trial }\end{array}$ & $\begin{array}{l}71 \text { LASH } \\
70 \text { LTH }\end{array}$ & $\begin{array}{l}\text { No statistically significant difference in surgical } \\
\text { complications and clinical outcomes }\end{array}$ \\
\hline $\begin{array}{l}\text { Harmanli et al. } \\
2009 \text { [11] }\end{array}$ & Retrospective & $\begin{array}{l}566 \mathrm{LASH} \\
450 \mathrm{LTH}\end{array}$ & $\begin{array}{l}\text { Similar overall short-term morbidity } \\
\text { Small statistically significant increase risk } \\
\text { of urinary tract injury with LTH }\end{array}$ \\
\hline $\begin{array}{l}\text { Mueller et al. } \\
2009 \text { [12] }\end{array}$ & Prospective & $\begin{array}{l}118 \text { LASH } \\
113 \mathrm{LTH}\end{array}$ & $\begin{array}{l}\text { LTH is comparable to LASH } \\
\text { Complication rates might be lower with LASH }\end{array}$ \\
\hline $\begin{array}{l}\text { Van Evert et al. } \\
2010[16]\end{array}$ & Retrospective & $\begin{array}{l}192 \mathrm{LASH} \\
198 \mathrm{LTH}\end{array}$ & $\begin{array}{l}\text { LASH is associated with higher long term } \\
\text { complications, while LTH is associated } \\
\text { with higher short term complications }\end{array}$ \\
\hline $\begin{array}{l}\text { Mousa et al. } \\
2009[13]\end{array}$ & Retrospective & $\begin{array}{l}122 \mathrm{LASH} \\
105 \mathrm{LTH}\end{array}$ & $\begin{array}{l}\text { LTH is associated with longer operating time, } \\
\text { but requires less postoperative analgesia than LASH }\end{array}$ \\
\hline $\begin{array}{l}\text { Cipullo et al. } \\
2009[14]\end{array}$ & Retrospective & $\begin{array}{l}157 \mathrm{LASH} \\
157 \mathrm{LTH}\end{array}$ & $\begin{array}{l}\text { LSH is a valid alternative to LTH } \\
\text { Major complications in LASH are significantly less than } \\
\text { those in LTH }\end{array}$ \\
\hline $\begin{array}{l}\text { Kafy et al. } \\
2009 \text { [17] }\end{array}$ & Retrospective & $\begin{array}{l}40 \text { LASH } \\
40 \text { LTH }\end{array}$ & $\begin{array}{l}\text { Both procedures result in similar improvement of } \\
\text { general health, body image, sexual function, } \\
\text { gastrointestinal and genitourinary functions }\end{array}$ \\
\hline $\begin{array}{l}\text { Nam et al. } \\
2008[18]\end{array}$ & Prospective & $\begin{array}{l}39 \text { LASH } \\
51 \text { LTH }\end{array}$ & $\begin{array}{l}\text { No significant change in quality of sexual } \\
\text { life after either procedure }\end{array}$ \\
\hline
\end{tabular}

Operating time

Two of the reviewed studies showed no difference in the operating time between LASH and LTH [11, 12]. Perhaps, the time used for suturing of the vaginal opening compensated that for morcellation. However, Mousa et al.
[13] and Cipullo et al. found that LTH was longer than LASH (Table 3). The discrepancy between the studies is unclear. In our practice, we often encounter uterus that is too large to be delivered vaginally forcing us to first partially morcellate the uterus. The time spent to morcellate the uterus adds to the operating time of LTH. We also found

Table 2 Demography of patients who underwent laparoscopic total hysterectomy (LTH) or laparoscopic supracervical hysterectomy (LASH)

\begin{tabular}{|c|c|c|c|c|c|}
\hline & Type of procedure & Age (years) & Parity & BMI & Uterine weight $(\mathrm{g})$ \\
\hline \multirow[t]{3}{*}{ Harmanli et al. 2009 [11] } & LASH & $43.8 \pm 5.9$ & $1.85 \pm 1.2$ & $28.5 \pm 6.9$ & $190.4 \pm 170$ \\
\hline & LTH & $44.6 \pm 7.9$ & $1.92 \pm 1.3$ & $27.9 \pm 6.6$ & $218.7 \pm 196.2$ \\
\hline & $P$ value & NS & NS & NS & 0.007 \\
\hline \multirow[t]{3}{*}{ Mueller et al. 2009 [12] } & LASH & $46.7 \pm 7.0$ & NA & $25.3 \pm 5.1$ & $286.2 \pm 209.3$ \\
\hline & LTH & $46.3 \pm 7.5$ & & $25.4 \pm 4.0$ & $264.8 \pm 133.6$ \\
\hline & $P$ value & NS & & NS & NS \\
\hline \multirow[t]{2}{*}{ Van Evert et al. 2010 [16] } & LASH & $44(28-60)$ & NA & NA & NA \\
\hline & LTH & $49(30-81)$ & & & \\
\hline \multirow[t]{3}{*}{ Mousa et al. 2009 [13] } & LASH & $45.7 \pm 0.6$ & $1.6 \pm 0.1$ & $26.6 \pm 0.4$ & $181 \pm 12.0$ \\
\hline & LTH & $45.9 \pm 0.7$ & $1.7 \pm 0.1$ & $26.8 \pm 1.5$ & $161 \pm 11.6$ \\
\hline & $P$ value & NA & NA & NA & NS \\
\hline \multirow[t]{3}{*}{ Cipullo et al. 2009 [14] } & LASH & $49.5 \pm 7.4$ & NA & $27.6 \pm 3.5$ & $162.7 \pm 112.7$ \\
\hline & LTH & $50.2 \pm 7.8$ & & $27.6 \pm 4.4$ & $169.7 \pm 116.6$ \\
\hline & $P$ value & NS & & NS & NS \\
\hline \multirow[t]{3}{*}{ Kafy et al. 2009 [17] } & LASH & $46.1 \pm 7.0$ & NA & NA & NA \\
\hline & LTH & $46.6 \pm 5.3$ & & & \\
\hline & $P$ value & NA & & & \\
\hline \multirow[t]{3}{*}{ Nam et al. 2008 [18] } & LASH & $41.9 \pm 4.7$ & $1.8 \pm 0.7$ & $22.5 \pm 2.4$ & NA \\
\hline & LTH & $46.3 \pm 3.7$ & $1.9 \pm 0.7$ & $22.8 \pm 3.2$ & \\
\hline & $P$ value & NS & NS & NS & \\
\hline
\end{tabular}


Table 3 Perioperative characteristics of patients who underwent laparoscopic total hysterectomy (LTH) or laparoscopic supracervical hysterectomy (LASH)

\begin{tabular}{|c|c|c|c|c|}
\hline & Harmanli et al. 2009 [11] & Mueller et al. 2009 [12] & Mousa et al. 2009 [13] & Cipullo et al. 2009 [14] \\
\hline \multirow{3}{*}{ Operating time (min) } & LTH $168 \pm 61$ & LTH $114 \pm 33.8$ & LTH $136 \pm 3.6$ & LTH $121.7 \pm 44.3$ \\
\hline & LASH $166 \pm 62$ & LASH $116.5 \pm 40$ & LASH $111 \pm 2.9$ & LASH $111.4 \pm 39.1$ \\
\hline & NS & NS & $P<0.001$ & $P<0.05$ \\
\hline \multirow[t]{3}{*}{ Hospital stay (day) } & LTH $1.4 \pm 0.7^{\mathrm{a}}$ & LTH $5.7 \pm 1.1$ & LTH $1.5 \pm 0.7$ & \multirow[t]{3}{*}{ NA } \\
\hline & LASH $1.2 \pm 0.6$ & LASH $5.3 \pm 1.6$ & LASH $1.8 \pm 0.2$ & \\
\hline & $\mathrm{P}<001$ & NS & NS & \\
\hline \multirow[t]{3}{*}{ Postoperative Hgb difference (g/dl) } & LTH $1.9 \pm 1.0$ & LTH $1.6 \pm 1.1$ & LTH 2.1 & \multirow{3}{*}{$\begin{array}{l}\text { LTH } 2.4 \pm 0.9 \\
\text { LASH } 2.1 \pm 0.9 \\
P<0.01\end{array}$} \\
\hline & LASH $1.9 \pm 0.9$ & LASH $1.5 \pm 1.4$ & LASH 1.9 & \\
\hline & NS & NS & NS & \\
\hline \multirow[t]{3}{*}{ Postoperative analgesia } & NA & $\begin{array}{l}\text { Ibuprofen ( } g \text { ) } \\
\text { LTH } 3.1 \pm 0.8\end{array}$ & $\begin{array}{l}\text { Morphine }(\mathrm{mg}) \\
\text { LTH } 28 \pm 2.9\end{array}$ & \multirow[t]{3}{*}{ NA } \\
\hline & & LASH $2.9 \pm 0.8$ & LASH $37.5 \pm 3.4$ & \\
\hline & & NS & $P<0.05$ & \\
\hline
\end{tabular}

$N A$ not available

${ }^{\text {a }}$ Recalculated to days

that coagulating and cutting with the same instrument make surgery faster. Clearly, there are many factors that can impact the operating time.

Milad et al. [15] compared the operating time of LASH and LAVH and found that LASH was significantly shorter than LAVH. This could be due to the time used to switch from laparoscopy to the vaginal part of the procedure.

\section{Hospital stay and blood loss}

The duration of hospital stay of LASH and LTH is comparable. In one study, the authors found that the hospital stay after LTH was about $5 \mathrm{~h}$ longer than LASH [11]. It is statistically different, but clinically does not make much difference.

Estimation of blood loss by laparoscopy is usually difficult and not accurate. Using Hgb level as an index of blood loss, three of four studies showed that there was no difference in the decrease in Hgb level after LASH or after LTH [11-13]. In contrast, Cipullo et al. [14] reported that LTH might be associated more blood loss than LASH. The reason is not clear.

\section{Postoperative pain}

Postoperative analgesia requirement after the two types of laparoscopic hysterectomy was evaluated in two studies [12, 13]. Mueller et al. [12] found no difference in ibuprofen requirement after LTH and after LASH. Although the study was prospective, it appears that the length of uterine incisions and the surgical technique of the surgeons were not standardized. In contrast, Mousa et al. found that the requirement of postoperative analgesia in LTH patients was lower than that in LASH patients [18]. This could be due to a larger incision $(\geq 15 \mathrm{~mm})$ required for the morcellator among women underwent LASH (Table 1).

\section{Postoperative complication}

Table 4 shows complications related to hysterectomy including urinary tract injury, cervical stump complication, conversion to laparotomy, reoperation, thromboembolic events, blood transfusion and fever.

Ureter and bladder injury

The incidence of bladder injury was $1.2-2 \%$ with TLH and $0-0.2 \%$ with LASH $[11,14]$.This could be related to more extensive separation of the bladder from the cervix in LTH. Yet, in one study the authors found similar incidence of bladder injury with the two hysterectomy techniques [13]. The incidence of ureter injury is comparable between the two techniques.

Cervical Stump complications and reoperation

One of the drawbacks of supracervical hysterectomy is the occurrence of cyclic bleeding from the cervical stump. For example, Van Evert et al. [16] described 6\% incidence of vaginal bleeding in the LASH group, and about one-third of 
Table 4 Intra- and postoperative characteristics of patients who underwent laparoscopic total hysterectomy (LTH) or laparoscopic supracervical hysterectomy (LASH)

\begin{tabular}{|c|c|c|c|c|c|c|c|c|c|c|}
\hline \multirow[t]{2}{*}{ Total } & \multicolumn{2}{|c|}{ Harmanli et al. 2009 [11] } & \multicolumn{2}{|c|}{ Mueller et al. 2009 [12] } & \multicolumn{2}{|c|}{ Van Evert et al. 2010 [16] } & \multicolumn{2}{|c|}{ Mousa et al. 2009 [13] } & \multicolumn{2}{|c|}{ Cipullo et al. 2009 [14] } \\
\hline & $\begin{array}{l}\text { LTH } 450 \\
n(\%) \\
\text { OR }(95 \% \text { CI })^{\mathrm{a}}\end{array}$ & $\begin{array}{l}\text { LASH } 566 \\
n(\%)\end{array}$ & $\begin{array}{l}\text { LTH } 113 \\
n(\%)\end{array}$ & $\begin{array}{l}\text { LASH } 118 \\
n(\%)\end{array}$ & $\begin{array}{l}\text { LTH } 198 \\
n(\%)\end{array}$ & $\begin{array}{l}\text { LASH } 192 \\
n(\%)\end{array}$ & $\begin{array}{l}\text { LTH } 105 \\
n(\%)\end{array}$ & $\begin{array}{l}\text { LASH } 122 \\
n(\%)\end{array}$ & $\begin{array}{l}\text { LTH } 157 \\
n(\%)\end{array}$ & $\begin{array}{l}\text { LASH } 157 \\
n(\%)\end{array}$ \\
\hline Thromboembolic event & $1(0.2)$ & 0 & NA & NA & NA & NA & 0 & $1(0.8)$ & 0 & $1(0.6)$ \\
\hline Ureter injury & NA & NA & $1(0.9)$ & 0 & 0 & $1(0.5)$ & $1(1.0)$ & 0 & $1(0.6)$ & 0 \\
\hline Bladder injury & $\begin{array}{l}10(2.2)^{\mathrm{b}} \\
4.75(1.21-18.56)^{\mathrm{b}}\end{array}$ & $3(0.5)^{\mathrm{b}}$ & NA & NA & NA & NA & $1(1.0)$ & $2(1.6)$ & $2(1.2)$ & 0 \\
\hline Blood transfusion & $8(1.8)$ & $9(1.6)$ & NA & NA & NA & NA & $1(1.0)$ & $5(4.1)$ & $1(0.6)$ & 0 \\
\hline Reoperation & $\begin{array}{l}4(0.9) \\
\text { NS }\end{array}$ & $1(0.2)$ & NA & NA & NA & NA & 0 & $5(4.1)$ & $2(1.2)$ & 0 \\
\hline Laparotomy conversion & $\begin{array}{l}26(5.8) \\
2.25(1.20-4.22)\end{array}$ & $23(4.1)$ & 0 & $\begin{array}{l}0 \\
\text { NS }\end{array}$ & $3(1.5)$ & $9(5)$ & 0 & $1(1.0)$ & NA & NA \\
\hline Urinary incontinence & NA & NA & NA & NA & $2(1)$ & $2(1)$ & 0 & $3(2.5)$ & NA & NA \\
\hline Vaginal bleeding & NA & NA & NA & NA & 0 & $12(6)$ & 0 & $1(0.8)$ & $1(0.6)$ & 0 \\
\hline Fever & $6(1.3)$ & $5(0.9)$ & NA & NA & $2(1)$ & $1(0.5)$ & $4(3.8)$ & $2(1.6)$ & $6(3.7)$ & $7(4.4)$ \\
\hline
\end{tabular}

$N A$ not available, $N S$ not significant

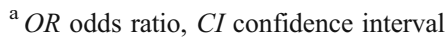

${ }^{\mathrm{b}}$ Includes both bladder and ureteric injuries

those patients needed subsequent surgical intervention. We previously reported that $4.1 \%$ of women after LASH required trachelectomy, mostly due to annoying cyclic vaginal bleeding [13]. This was despite coagulation of the endocervix at the completion of the procedure.

Conversion to laparotomy and other complications

Conversion to laparotomy from LASH or TLH appears to be comparable (Table 3). This is mostly related to technical difficulties, the presence of extensive adhesions and uncontrolled bleeding [11, 16]. The incidence of blood transfusion, thromboembolic events, urinary incontinence and febrile morbidity are also similar.

\section{Quality of life}

Table 5 demonstrates the quality of life after LTH and LASH.

General health and dyspareunia

General health or dyspareunia following LTH and LASH are comparable.

Table 5 Quality of Life after laparoscopic total hysterectomy (LTH) or laparoscopic supracervical hysterectomy (LASH)

\begin{tabular}{|c|c|c|c|c|c|c|c|c|}
\hline & \multicolumn{4}{|c|}{ Kafy et al. $2009[17]^{a}$} & \multicolumn{4}{|c|}{ Nam et al. $2008[18]^{\mathrm{b}}$} \\
\hline & \multicolumn{2}{|l|}{ LTH 40} & \multicolumn{2}{|l|}{ LASH 40} & \multicolumn{2}{|c|}{ LTH 51} & \multicolumn{2}{|c|}{ LASH 39} \\
\hline & Before & After & Before & After & Before & After & Before & After \\
\hline General health & $\begin{array}{l}2.2 \pm 0.4 \\
P<0.001\end{array}$ & $\begin{array}{l}1.9 \pm 0.4 \\
P<0.005\end{array}$ & $\begin{array}{l}2.3 \pm 0.5 \\
\text { NA }\end{array}$ & $\begin{array}{l}2.1 \pm 0.6 \\
\text { NA }\end{array}$ & NA & NA & NA & NA \\
\hline Self-image & $\begin{array}{l}2.2 \pm 0.4 \\
P<0.01\end{array}$ & $\begin{array}{l}2.1 \pm 0.4 \\
P<0.006\end{array}$ & $\begin{array}{l}2.4 \pm 0.5 \\
\text { NA }\end{array}$ & $\begin{array}{l}2.1 \pm 0.4 \\
\text { NA }\end{array}$ & $\begin{array}{l}\text { NA } \\
\text { NA }\end{array}$ & $\begin{array}{l}\text { NA } \\
\text { NA }\end{array}$ & NA & NA \\
\hline Sexual satisfaction & $\begin{array}{l}2.5 \pm 0.6 \\
P<0.001\end{array}$ & $\begin{array}{l}2.2 \pm 0.5 \\
P<0.002\end{array}$ & $\begin{array}{l}2.5 \pm 0.7 \\
\mathrm{NS}\end{array}$ & $\begin{array}{l}2.3 \pm 0.6 \\
\mathrm{NS}\end{array}$ & 1.98 & 1.9 & 2.1 & 1.95 \\
\hline Dyspareunia & $\begin{array}{l}2.4 \pm 0.6 \\
P<0.001\end{array}$ & $\begin{array}{l}1.7 \pm 0.5 \\
P<0.002\end{array}$ & $\begin{array}{l}1.9 \pm 0.7 \\
\text { NA }\end{array}$ & $\begin{array}{l}1.6 \pm 0.5 \\
\text { NA }\end{array}$ & $2^{\mathrm{c}}$ & 2 & 4 & 1 \\
\hline Time to intercourse & $\begin{array}{l}\text { NA } \\
\text { NA }\end{array}$ & $\begin{array}{l}\text { NA } \\
\text { NA }\end{array}$ & $\begin{array}{l}5.78 \pm 1.13 \\
P<0.001\end{array}$ & $4.92 \pm 1.2$ & & & & \\
\hline
\end{tabular}

${ }^{\text {a }}$ Kafy et al.'s scale: 1 very satisfied, 2 satisfied, 3 somewhat satisfied, 4 unsatisfied, 5 very unsatisfied

${ }^{\mathrm{b}}$ Nam et al.'s scale: 1 not satisfied, 2 somewhat, 3 satisfied

${ }^{\mathrm{c}}$ Number of patients 
Sexual satisfaction and time to first intercourse

Contrary to a previous report of impaired sexual satisfaction after total hysterectomy [7], Kafy et al. could not demonstrate any difference in sexual satisfaction or self image after LTH or LASH [17]. Nam et al. [18] reported earlier resumption of sexual activity in the LASH group compared to LTH group. This might be related to health personnel's advice to avoid sexual contact until 6-8 weeks after surgery. Indeed, early sexual intercourse is one of the predisposing factors for vaginal vault prolapse after total hysterectomy [19].

\section{Conclusions}

Besides a slightly increased incidence of bladder injury with LTH and of complications related to cervical retention after LASH, the two laparoscopic techniques appear comparable. Both techniques lead to improvement in dyspareunia. Following the studies demonstrating similar sexual function with and without cervical preservation, we performed mainly LTH. In addition to post-LASH cervical bleeding, retaining the cervix is associated with the concerns of cancer development in the cervical stump. This is especially important in the regions with poor follow-up and lack of annual cervical smears. The risk of developing carcinoma in the cervical stump is less than $0.03 \%$ in women who had had previous normal cervical cytology [20].

Other cervical stump complications include obstructive mucocele, infection and sepsis [21, 22]. As there is no risk of vault prolapse, LASH could be followed by early resumption of sexual activity [23, 24]. The issue of retaining or removing the cervix along with the uterine body should be discussed thoroughly with the patient. For those opting for cervical preservation, they should be instructed to have annual cervical smear.

We conclude that LASH is an alternative to total laparoscopic hysterectomy with less incidence of bladder injury and earlier resumption of sexual activity. Cervical preservation carries a small risk of bleeding and malignant transformation that might require further intervention. Total laparoscopic hysterectomy requires less postoperative analgesia, has lower incidence of reoperation and eliminates the complications associated with cervical stump. However, it is associated with increased urinary tract injury and rarely with vault prolapse. The decision to perform either procedure depends on the surgeon's expertise and the preference of both surgeon and the patient.

Conflicts of interest The authors report no conflicts of interest. The authors alone are responsible for the content and writing of the paper.

\section{References}

1. The Canadian Institute for Health Information (2006) Health Indicator Reports; Hysterectomy

2. Division of Reproductive Health, National Center for Chronic Disease Prevention and Health Promotion, http://www.cdc.gov/ mmwr/preview/mmwrhtml/ss5105a1.htm. Accessed 3 Aug 2010

3. Women's Health Matters (2002) Hysterectomies too Frequent in Canada? http://www.womenshealthmatters.ca/news/news_show. cfm?number $=170$. Accessed 3 Aug 2010

4. Sokol AI, Green IC (2009) Laparoscopic hysterectomy. Clin Obstet Gynecol 52:304-312

5. Jenkins TR (2004) Laparoscopic supracervical hysterectomy. Am J Obstet Gynecol 191:1875-1884

6. Bojahr B, Raatz D, Schonleber G, Abri C, Ohlinger R (2006) Perioperative complication rate in 1706 patients after a standardized laparoscopic supracervical hysterectomy technique. J Minim Invasive Gynecol 13:183-189

7. Kilkku P, Gronroos M, Hirvonen T, Rauramo L (1983) Supravaginal uterine amputation vs. hysterectomy. Effects on libido and orgasm. Acta Obstet Gynecol Scand 62:147-152

8. Thakar R, Ayers S, Clarkson P, Stanton S, Manyonda I (2002) Outcomes after total versus subtotal abdominal hysterectomy. N Engl J Med 347:1318-1325

9. Gimbela H, Zobbea V, Andersena BM, Filtenborge T, Gluudd C, Taborb A, The Danish Hysterectomy Group (2003) Randomised controlled trial of total compared with subtotal hysterectomy with one-year follow up results. BJOG 110:1088-1098

10. Learman L, Summit R, Varner RE, McNeeley SG, Goodman-Gruen D, Richter HE, Feng L, Showstack J, Ireland C, Vittinghoff E, Helley SB, Washington AE (2003) A randomized comparison of total or supracervical hysterectomy: surgical complications and clinical outcomes. Obstet Gynecol 102:453-462

11. Harmanli OH, Tunitsky E, Esin S, Citil A, Knee A (2009) A comparison of short-term outcomes between laparoscopic supracervical and total hysterectomy. Am J Obstet Gynecol 201(536):e1-e7

12. Mueller A, Renner SP, Haeberle L, Lermann J, Oppelt P, Beckmann MW, Thiel F (2009) Comparison of total laparoscopic hysterectomy (TLH) and laparoscopy-assisted supracervical hysterectomy (LASH) in women with uterine leiomyoma. Eur J Obstet Gynecol Reprod Biol 144:76-79

13. Mousa A, Zarei A, Tulandi T (2009) Changing practice from laparoscopic supracervical hysterectomy to total hysterectomy. J Obstet Gynaecol Can 31:521-525

14. Cipullo L, De Paoli S, Fasolino L, Fasolino A (2009) Laparoscopic supracervical hysterectomy compared. JSLS 13:370-375

15. Milad MP, Morrison K, Sokol A, Miller D, Kirkpatrick L (2001) A comparison of laparoscopic supracervical hysterectomy vs. laparoscopically assisted vaginal hysterectomy. Surg Endosc 15:286-288

16. Van Evert JS, Smeenk JM, Dijkhuizen FP, de Kruif JH, Kluivers KB (2010) Laparoscopic subtotal hysterectomy versus laparoscopic total hysterectomy: a decade of experience. Gynecol Surg 7:9-12

17. Kafy S, Al-Sannan B, Kabli N, Tulandi T (2009) Patient satisfaction after laparoscopic total or supracervical hysterectomy. Gynecol Obstet Invest 67:169-172

18. Nam A, Cho SH, Seo SK, Jeon YE, Kim HY, Choi YS, Lee BS (2008) Laparoscopic total hysterectomy versus laparoscopic supracervical hysterectomy: the effect on female sexuality. Women's Med 1:43-47

19. Agdi M, Al-Ghafri W, Antolin R, Arrington J, O'Kelley K, Thomson AJ, Tulandi T (2009) Vaginal vault dehiscence after hysterectomy. J Minim Invasive Gynecol 16:313-317

20. Storm HH, Clemmensen IH, Manders T, Brinton LA (1992) Supravaginal uterine amputation in Denmark 1978-1988 and risk of cancer. Gynecol Oncol 45:198-201 
21. Okaro EO, Jones KD, Sutton C (2001) Long term outcome following, aparoscopic supracervical hysterectomy. BJOG 108:1017-1020

22. Huang JYJ, Ziegler C, Tulandi T (2005) Cervical stump necrosis and septic shock after laparoscopic supracervical hysterectomy. J Min Inv Gynecol 12:162-164

23. Charles JL, Jamse FD (1996) Early outcomes of laparoscopic assisted vaginal hysterectomy versus laparoscopic supra cervical hysterectomy. J Am Assoc Gynecol Laparosc 3:251-256
24. Diaa EM, Wahba MF, Chitranjan LF, Jean MW (2004) Laparoscopic supracervical hysterectomy versus laparoscopic assisted vaginal hysterectomy. J Am Assoc Gynecol Laparosc 11:175-180

25. Morelli M, Noia R, Chiodo D, Mocciaro R, Costantino A, Caruso MT, Cosco C, Lucia E, Curcio B, Gullì G, Amendola G, Zullo F (2007) Laparoscopic supracervical hysterectomy versus laparoscopic total hysterectomy: a prospective randomized study. Minerva Gynecol 59:1-10 